\title{
KAJIAN AWAL PENGOLAHAN SAMPAH KAWASAN WISATA PANTAI CAROCOK KOTA PAINAN
}

\author{
Rizki Aziz $^{1)}$, Yommi Dewilda ${ }^{1)}$, dan Busrita Exgia Putri ${ }^{1)}$ \\ ${ }^{1}$ Fakultas Teknik, Universitas Andalas \\ email: rizkiaziz@eng.unand.ac.id
}

\begin{abstract}
Abstrak: Kawasan wisata adalah salah satu sumber sampah kota yang terus meningkat timbulan sampahnya seiring dengan meningkatnya kunjungan wisatawan yang dipacu oleh peningkatan pembangunan wisata, termasuk di Pantai Carocok Kota Painan. Penelitian ini bertujuan untuk menganalisis timbulan sampah, komposisi, dan potensi daur ulang sampah wisata Pantai Carocok, dan memberikan rekomendasi pengolahan sampah sebagai bagian dari sistem pengelolaan sampah Pantai Carocok kedepannya. Timbulan sampah Pantai Carocok sebesar 6.149 L/hari atau 578,01 $\mathrm{kg} / \mathrm{hari}$ dengan komposisi sampah dominan adalah sampah makanan $28,32 \%$, plastik $26,30 \%$, kertas $17,46 \%$, dan sampah halaman $12,55 \%$. Potensi daur ulang sampah yang terbesar yaitu sampah logam $93,55 \%$, sampah plastik $86,25 \%$ dan kaca $54,89 \%$. Pengolahan sampah yang dapat dilakukan berupa pengomposan untuk sampah makanan dan halaman, dan didaur ulang untuk sampah plastik, kertas, kaca, dan logam, sedangkan sisanya dapat ditransportasikan ke Tempat Pemrosesan Akhir sampah. Pengolahan sampah dapat dilakukan di Tempat Pengolahan Sampah berbasis reduce, reuse, recycle (TPS 3R).
\end{abstract}

Kata kunci: pengolahan, sampah wisata, TPS 3R, Pantai Carocok

\begin{abstract}
The tourism area is one of the sources of municipal solid waste which continues to increase its waste generation in line with the increase in tourist visits that are spurred by increased tourism development, including in the Carocok Beach of Painan City. This study aims to analyze the generation of waste, composition, and potential for recycling of Carocok Beach tourism waste, and provide recommendations for processing waste as part of the future Carocok Beach waste management system. Carocok Beach waste generation is 6,149 L/day or $578.01 \mathrm{Kg} /$ day with the composition of the dominant waste are food waste $28.32 \%$, plastic $26.30 \%$, paper $17.46 \%$, and yard waste $12.55 \%$. The biggest potential for waste recycling is metal waste $93.55 \%$, plastic waste $86.25 \%$ and glass 54.89\%. Waste processing can be done in the form of composting for food and yard waste, and recycled for plastic, paper, glass, and metal waste, while the rest can be transported to the landfill. Waste processing can be done in a waste treatment facility based on reduce, reuse, recycle (TPS 3R).
\end{abstract}

Keywords: processing, tourism solid waste, TPS 3R, Carocok beach

\section{PENDAHULUAN}

Kawasan ibukota Kabupaten Pesisir Selatan memiliki sebuah objek wisata pantai yang sangat indah yakni objek wisata Pantai Carocok. Pantai ini memiliki pasir putih serta air jernih, tepi pantai yang landai, serta dapat digunakan sebagai sarana berenang bagi anak-anak dan orang dewasa. Pantai ini berhadapan dengan dua buah pulau yaitu Pulau Kereta yang dihubungkan oleh jembatan dengan pantai Carocok dan Pulau Cingkuak yang dapat dikunjungi dengan perahu atau speedboat.
Pantai Carocok merupakan salah satu objek wisata yang sudah dikenal sejak dulu. Pantai ini juga selalu ramai dikunjungi oleh masyarakat baik dari daerah sendiri maupun dari mancanegara saat musim liburan dan lebaran.

Ramainya pegunjung atau wisatawan lokal maupun mancanegara di Pantai Carocok dapat menimbulkan dampak ekonomi yang positif seperti pendapatan daerah dari restribusi uang masuk pantai. Selain itu di sekitar pantai juga banyak terdapat aktivitas jual beli souvenir dan pedagang makanan baik pedagang kaki 
lima maupun toko atau lapak, fasilitas taman bermain anak pun sudah ada di Pantai Carocok. Selain pengaruh positif, tentu ada pengaruh negatif yang dapat ditelusuri sebagai kerugian yang timbul akibat pengembangan pariwisata. Pengaruh negatif terhadap aspek lingkungan yaitu adanya polusi udara, pencemaran air, serta penurunan kualitas lingkungan karena sampah di sekitar kawasan wisata (Suzanna, 2013). Setiap permasalahan yang dihadapi oleh tempat wisata akan berdampak terhadap wisatawan yang berkunjung ke tempat wisata tersebut. Salah satu permasalahan lingkungan adalah sampah yang akan membuat wisatawan tidak nyaman dan tidak betah berada di kawasan wisata tersebut dan berdampak kepada berkurangnya jumlah wisatawan yang berkunjung.

Sampah adalah sisa kegiatan seharihari manusia dan/atau proses alam yang berbentuk padat. Sampah terdiri dari sampah rumah tangga, sampah sejenis rumah tangga dan sampah spesifik. Sampah pariwisata termasuk ke dalam sampah sejenis sampah rumah tangga. Sampah sejenis sampah rumah tangga wajib untuk dikelola yaitu dengan cara pengurangan dan penanganan sampah yang berwawasan lingkungan (Undangundang No. 18 tahun 2008).

Pengelolaan sampah pariwisata Kota Painan di kelola oleh Dinas Lingkungan Hidup (DLH) Kota Painan. Pengelolaan sampah yang sudah ada di kawasan pariwisata seperti pewadahan, pengangkutan dan pembuangan sampah ke Tempat Pemrosesan Akhir (TPA) yang sudah diatur oleh DLH Kota Painan.

Penelitian timbulan, komposisi, potensi daur ulang, dan karakteristik sampah kawasan wisata di Kota Painan belum pernah dilakukan sebelumnya. Data timbulan, komposisi, potensi daur ulang dan karakteristik sampah suatu kota dan kawasan berguna untuk perencanaan sistem pengelolaan persampahan, seperti penentuan pewadahan, pengumpulan, pengangkutan, desain fasilitas pengolahan dan desain TPA (Damanhuri dan Padmi, 2016).

Penelitian tentang sampah wisata telah banyak dipublikasikan baik secara internasional ataupun nasional. Kajian ini dilakukan berbagai lokasi tempat wisata yaitu resort wisata di hutan Kashmir (Bhat dkk, 2014), wisata kota di Vietnam (Hoang dkk, 2017), wisata pulau di Langkawi (Shamshiry dkk, 2011), desa wisata di Malang (Purmada dkk, 2016), wisata bukit di Sintang (Naltaru dkk, 2014), wisata pelabuhan (Wijaya dan Trihadiningrum, 2014), wisata gunung (Oktiasari, 2018) dan wisata pantai di China (Liu dkk, 2017). Untuk Sumatera Barat sendiri sebelumnya sudah dilakukan beberapa penelitian yang berlokasi pada pantai, danau (Aziz dan Putra), lembah (Riva'i, 2018), desa wisata (Yeni, 2019), dan wisata kota (Jefri dan Aziz, 2018, dan Aziz dkk, 2019). Untuk lokasi pantai telah dilakukan pada kawasan wisata Pantai Pariaman (Aziz dan Mira, 2019), Pantai Air Manis Padang (Aziz dkk, 2020), dan Pantai Padang (Adfuza, 2019).

Oleh karena itu hasil dari penelitian diharapkan dapat dipertimbangkan untuk data timbulan sampah khususnya untuk kawasan wisata Kota Painan yang dilakukan sesuai dengan peraturan dan tata cara penelitian yang berlaku di Indonesia. Selain itu hasil penelitian ini juga dapat dimanfaatkan oleh pemerintah setempat untuk mengevaluasi dan mengembangkan perencanaan pengelolaan persampahan kawasan wisata Kota Painan menjadi lebih baik.

Tujuan penelitian ini adalah menganalisis timbulan sampah, komposisi, potensi daur ulang sampah Kawasan Wisata Pantai Carocok, dan merekomendasikan pengolahan sampah yang dapat dilakukan untuk sistem pengelolaan sampah Pantai Carocok kedepannya.

Timbulan sampah adalah banyaknya sampah yang timbul dari masyarakat dalam satuan volume maupun berat 
perkapita perhari, atau perluas bangunan, atau perpanjang jalan (BSN, 2002). Banyaknya sampah yang dihasilkan dari sebuah kegiatan akan menentukan banyaknya sampah yang harus dikelola oleh sebuah kota. Timbulan sampah dapat dinyatakan dalam satuan volume liter/orang/hari (1/o/h) atau liter/meter persegi bangunan/hari $\left(1 / \mathrm{m}^{2} / \mathrm{h}\right)$ dan dengan satuan berat kilogram/orang/hari $(\mathrm{kg} / \mathrm{o} / \mathrm{h})$ atau kilogram/meter persegi bangunan/hari $\left(\mathrm{kg} / \mathrm{m}^{2} / \mathrm{h}\right)$ (Damanhuri dan Padmi, 2016).

Komposisi sampah merupakan penggambaran dari masing-masing komponen yang terdapat pada sampah dan distribusinya. Biasanya dinyatakan dalam persen berat basah (\% berat-basah) (Damanhuri dan Padmi, 2016).

Potensi daur ulang adalah kemampuan yang ada dalam komponen sampah yang dapat dikembangkan untuk proses pengolahan sampah yang menghasilkan produk baru. Upaya daur ulang akan berhasil baik apabila dilakukan pemilihan dan pemisahan komponen sampah dimulai dari sumber sampai proses akhirnya (Damanhuri dan Padmi, 2016).

\section{METODE PENELITIAN}

Penelitian dilakukan dalam beberapa tahapan yaitu studi literatur, pengumpulan data, penelitian lapangan dan laboratorium, hasil dan pembahasan hasil penelitian.

Acuan dan dasar dalam pengerjaan kajian ini menggunakan studi literatur yang berhubungan dengan timbulan, komposisi, potensi daur ulang dan karakteristik sampah di Kawasan Wisata Pantai Carocok Kota Painan.

Pengumpulan data yang dilakukan ada dua jenis data yang digunakan, yaitu data sekunder dan data primer. Data sekunder dapat diperoleh dari instansi terkait, dan sumber-sumber lainnya yang relevan. Sedangkan untuk data primer diperoleh dari hasil sampling, hasil pengukuran serta penyebaran kuisioner.

Data sekunder dalam kajian ini, meliputi: a) gambaran umum kawasan
Wisata Pantai Carocok Kota Painan yang meliputi luas dan batasan wilayah dari kantor Pusat Statistik Kota Painan; b) jumlah pengunjung kawasan wisata Kota Painan dari Dinas Pariwisata, Pemuda, dan Olahraga Kabupaten Pesisir Selatan; c) jumlah sarana dan prasarana di Kawasan Wisata Pantai Carocok Kota Painan; d) luas masing-masing sarana wisata di Kawasan Wisata Pantai Carocok Kota Painan; e) peta pendukung seperti peta batas administratif dan tata guna lahan.

Lokasi pengambilan sampel dilakukan di kawasan wisata Pantai Carocok dan kawasan wisata Pulau Cingkuak yang ada di Kota Painan. Hal ini bertujuan untuk memudahkan dalam melakukan pengambilan sampel karena lokasi pantai dan pulau berdekatan. Pemilihan pantai dan pulau ditentukan berdasarkan perkembangan sektor pariwisata (sarana dan prasarana) dan banyaknya pengunjung yang datang ke kawasan wisata tersebut.

Berdasarkan SNI 19-3694-1994 (BSN, 1994) jumlah sampel yang berasal dari fasilitas lainnya yang tidak tercantum pada Tabel 2.7 diambil $10 \%$ dari jumlah keseluruhan atau sekurang-kurangnya 1 (satu). Jumlah sarana dan sampel sampah Kawasan Wisata Pantai Carocok Painan ditampilkan pada Tabel 1.

Tabel 1. Jumlah Sarana dan Sampel Sampah

\begin{tabular}{lcc}
\hline Sarana & Jumlah & Sampel \\
\hline Rumah makan & 3 & 1 \\
Pertokoan & 40 & 4 \\
Pedagang kaki lima & 25 & 3 \\
Pentas seni & 1 & 1 \\
Taman bermain & 1 & 1 \\
Taman & 1 & 1 \\
Gazebo & 1 & 1 \\
Mushalla & 2 & 1 \\
Hotel/wisma & 5 & 1 \\
\hline Total & & 15 \\
\hline
\end{tabular}

Kuisoner sebanyak 20 disebarkan di beberapa fasilitas yang ada di Pantai Carocok dan Pulau Cingkuak Kota Painan yang memiliki jumlah fasilitas lebih dari 1 . Hal ini berguna untuk mengambil data awal dalam pemilihan titik lokasi sampling, sedangkan pertimbangan untuk titik pemilihan lokasi sampling, sebagai berikut: a) jumlah pengunjung, yang lebih 
banyak yang diambil yang dapat mewakili dari seluruh fasilitas tersebut; dan b) luas fasilitas, yang besar diambil sebagai perwakilan untuk seluruh fasilitas yang ada di lokasi Pantai Carocok dan Pulau Cingkuak.

Pengumpulan data primer berupa data timbulan, komposisi, dan potensi daur ulang sampah Kawasan Wisata Pantai Carocok dan Pulau Cingkuak diperoleh dari dua lokasi yakni di lapangan dan Laboratorium Buangan Padat Jurusan Teknik Lingkungan. Metode sampling dan pengukuran untuk timbulan dan komposisi sampah mengikuti SNI 19-3964-1994. Sedangkan untuk potensi daur ulang dilakukan dengan menggunakan pendekatan pemilahan sampah-sampah yang dapat didaur ulang menurut komposisinya. Kemudian sampah ditimbang dan dicatat berat dan persen sampah yang berpotensi didaur ulang sesuai data komponen sampah yang dibeli oleh pelaku bisnis sampah. Formula dalam perhitungan timbulan sampah, komposisi, dan potensi daur ulang adalah sebagai berikut:

a. Rumus timbulan per hari:

$$
\text { Volume sampah (L) }
$$

$$
=\overline{\text { jumlah unit penghasil sampah ( } \left.\mathrm{m}^{2} / \text { orang }\right)}
$$

b. Rumus komposisi (\% berat):

$$
=\frac{\text { berat komponen sampah }(\mathrm{kg})}{\text { berat total sampah yang diukur }(\mathrm{kg})} \times 100 \%
$$

c. Rumus potensi daur ulang (\%):

$$
=\frac{\text { berat komponen dapat didaur ulang }}{\text { berat total sampah dari sumber }} \times 100 \%
$$

\section{HASIL DAN PEMBAHASAN \\ Timbulan Sampah}

Berdasarkan penelitian yang telah dilakukan diperoleh fluktuasi satuan timbulan sampah yang dihasilkan perharinya. Sampling dilakukan selama 8 hari berturut-turut pada hari Sabtu ke Sabtu. Satuan timbulan sampah Pantai Carocok Kota Painan dihitung dalam satuan berat dan satuan volume berdasarkan jiwa dan luas dari fasilitas atau sumber masing-masing.

Sampah yang dihasilkan dari kawasan wisata Pantai Carocok Kota Painan berasal dari jenis sampah yang berbeda-beda. Jenis sampah terbagi menjadi 2 jenis yaitu sampah organik dan anorganik. Sampah organik terdiri atas komponen sampah sisa makanan, kertas, plastik, tekstil, karet, sampah halaman, dan kayu. Pada sampah anorganik terdiri atas komponen sampah kaca, besi dan lain-lainnya. Untuk besi terbagi lagi atas logam ferrous dan logam non ferrous. Hal ini yang nantinya akan mempengaruhi fluktuasi nilai satuan timbulan yang mengalami fluktuasi pada setiap fasilitas yang ada.

Hasil perhitungan satuan timbulan sampah kawasan wisata Pantai Carocok Kota Painan dari masing-masing fasilitas secara keseluruhan dapat dilihat pada Tabel 2.

Tabel 2. Satuan Timbulan Sampah

\begin{tabular}{lllcc}
\hline \multirow{2}{*}{ Sarana } & \multicolumn{2}{c}{ Berat $\mathbf{( k g )}$} & \multicolumn{2}{c}{ Volume $(\mathbf{L})$} \\
\cline { 2 - 5 } & $\mathbf{K g} / \mathbf{o} / \mathbf{h}$ & $\mathbf{K g} / \mathbf{m}^{\mathbf{2}} / \mathbf{h}$ & $\mathbf{L} / \mathbf{o} / \mathbf{h}$ & $\mathbf{L} / \mathbf{m}^{\mathbf{2}} / \mathbf{h}$ \\
\hline $\begin{array}{l}\text { Pedagang } \\
\text { kaki lima }\end{array}$ & 0,020 & 0,063 & 0,653 & 2,496 \\
Toko/lapak & 0,015 & 0,014 & 0,506 & 0,492 \\
Rumah & 0,029 & 0,043 & 0,577 & 0,850 \\
makan & & & & \\
Taman & 0,005 & 0,001 & 0,091 & 0,022 \\
Mushalla & 0,005 & 0,014 & 0,122 & 0,314 \\
Gazebo & 0,003 & 0,001 & 0,076 & 0,027 \\
Hotel & 0,019 & 0,011 & 0,428 & 0,255 \\
Parkir & 0,012 & 0,001 & 0,215 & 0,025 \\
Pentas seni & 0,008 & 0,008 & 0,265 & 0,262 \\
Pulau & 0,004 & 0,012 & 0,139 & 0,457 \\
\hline Rerata & 0,012 & 0,019 & 0,307 & 0,520 \\
\hline
\end{tabular}

Hasil pengolahan data menunjukkan rata-rata timbulan sampah dari fasilitas wisata pantai Carocok Kota Painan berdasarkan jiwa dan luas dalam satuan berat adalah $0,012 \mathrm{~kg} / \mathrm{o} / \mathrm{h}$ dan 0,019 $\mathrm{kg} / \mathrm{m}^{2} / \mathrm{h}$, dan berdasarkan jiwa dan luas dalam satuan volume adalah $0,307 \mathrm{l} / \mathrm{o} / \mathrm{h}$ dan $0,5201 / \mathrm{m}^{2} / \mathrm{h}$. Perbedaaan nilai maksimum dan minimum yang diperoleh dari masing-masing fasilitas yang dijadikan titik sampel disebabkan karena adanya perbedaan dari jumlah pengunjung yang datang dan perbedaan jenis sampahnya.

Berdasarkan Tabel 2, satuan timbulan maksimum dalam satuan berat berdasarkan jiwa didapatkan pada sampah rumah makan yaitu sebesar $0,029 \mathrm{~kg} / \mathrm{o} / \mathrm{h}$ dan 
satuan timbulan minimumnya didapatkan pada sampah gazebo yaitu sebesar 0,003 $\mathrm{kg} / \mathrm{o} / \mathrm{h}$. Berdasarkan luas didapatkan satuan timbulan maksimum pada sampah PKL sebesar $0,083 \mathrm{~kg} / \mathrm{m}^{2} / \mathrm{h}$ dan satuan timbulan minimumya didapatkan pada sampah gazebo sebesar $0,001 \mathrm{~kg} / \mathrm{m}^{2} / \mathrm{h}$.

Satuan timbulan maksimum berdasarkan jiwa terdapat pada sampah rumah makan dimana pada rumah makan didominasi oleh sampah sisa makanan yang memiliki kandungan airnya lebih banyak sehingga memiliki berat yang lebih besar dari lainnya. Sedangkan berdasarkan luas, nilai maksimumnya terdapat pada PKL. Hal ini disebabkan adanya perbedaan jenis sampah saat dilakukan pengukuran dan adanya perbedaan berat sampah yang didapatkan dari PKL. Satuan timbulan minimumnya didapatkan pada sampah yang sama yaitu gazebo. Hal ini dikarenakan pada gazebo ditemukan sampah plastik berupa minuman dalam kemasan botol dan kertas yang didominasi oleh sampah tissue yang membuat berat sampahnya kecil.

Berdasarkan jiwa dalam satuan volume, didapatkan nilai maksimum pada sampah PKL sebesar $0,653 \mathrm{l} / \mathrm{o} / \mathrm{h}$ dan nilai minimumnya didapatkan pada sampah gazebo sebesar $0,076 \mathrm{l} / \mathrm{o} / \mathrm{h}$. Sedangkan berdasarkan luas, satuan timbulan maksimumnya didapatkan pada PKL sebesar 2,496 1/m $/ \mathrm{m}^{2} \mathrm{~h}$ dan satuan timbulan minimumnya didapatkan pada sampah taman sebesar $0,022 \quad 1 / \mathrm{m}^{2} / \mathrm{h}$. Satuan timbulan maksimum baik berdasarkan jiwa maupun luas didapatkan pada sampah yang sama yaitu PKL. Hal ini dapat disebabkan oleh komposisi dari setiap penghasil sampah. Pada PKL selain sampah makanan banyak juga ditemukan sampah ampas tebu, cangkang telur, maupun sisa-sisa tusuk sate yang membuat volumenye besar. Dalam satuan volume, nilai satuan timbulan minimum baik berdasarkan jiwa maupun luas didapatkan pada sumber sampah yang berbeda. Hal ini dapat disebabkan karena adanya perbedaan jenis sampah yang didapatkan saat pengukuran dan adanya perbedaan berat sampah yang didapatkan dari gazebo dan taman.

Secara umum nilai timbulan sampah kawasan wisata Pantai Carocok Kota Painan terbanyak terjadi pada akhir pekan yaitu hari Sabtu dan hari Minggu. Hal ini dipengaruhi oleh banyaknya pengunjung yang datang ke kawasan wisata karena merupakan hari libur. Jumlah kunjungan untuk semua fasilitas yang ada di pantai meningkat pada hari Sabtu, Minggu dan Selasa menyebabkan nilai timbulan sampah semakin tinggi. Hal ini disebabkan karena hari Sabtu dan Minggu merupakan akhir pekan, sedangkan hari Selasa merupakan hari libur.

Sedangkan jumlah timbulan perhari yang didapatkan di kawasan wisata Pantai Carocok Kota Painan secara total adalah $6.149 \mathrm{~L} / \mathrm{hari}$, leboh detail dapat dilihat pada Tabel 3.

Tabel 3. Timbulan Sampah

\begin{tabular}{lccr}
\hline \multirow{1}{*}{ Sarana } & Pengunjung & $\begin{array}{c}\text { Satuan } \\
\text { timbulan }\end{array}$ & Timbulan \\
\cline { 2 - 4 } & Orang & L/o/h & L/h \\
\hline Pedagang & 2.522 & 0,653 & 1.647 \\
kaki lima & & & \\
Toko/lapak & 8.745 & 0,506 & 4.424 \\
Rumah & 515 & 0,577 & 297 \\
makan & & & \\
Taman & 1.096 & 0,091 & 100 \\
Mushalla & 467 & 0,122 & 57 \\
Gazebo & 326 & 0,076 & 25 \\
Hotel & 304 & 0,428 & 120 \\
Parkir & 1.363 & 0,215 & 294 \\
Pentas seni & 172 & 0,265 & 45 \\
Pulau & 4.502 & 0,139 & 626 \\
\hline Total & & & 6.149 \\
\hline
\end{tabular}

Selain itu melalui perbandingan data timbulan sampah dalam berat dengan timbulan sampah dalam volume didapatkan berat jenis sampah rerata yaitu $0,094 \mathrm{~kg} / \mathrm{L}$. Sehingga timbulan sampah dalam berat untuk tiap harinya adalah $578,01 \mathrm{~kg} / \mathrm{hari}$.

\section{Komposisi Sampah}

Hasil penelitian komposisi sampah wisata Pantai Carocok Kota Painan didapatkan hasil yang menunjukkan bahwa 
komposisi terbanyak adalah sampah organik (sampah makanan, sampah plastik, sampah kertas, sampah halaman, sampah kayu, dan sampah tekstil) dengan persentase $89,42 \%$, sedangkan persentase sampah anorganik (sampah kaca, sampah logam non ferrous, dan lain-lain) sebesar 10,58\%. Data perhitungan komposisi sampah rata-rata komposisi sampah wisata pantai Carocok Kota Painan dapat dilihat pada Tabel 4.

Tabel 4. Komposisi Sampah

\begin{tabular}{lr}
\hline Komponen & Komposisi (\%) \\
\hline Organik & \\
\hline Sampah Makanan & 28,32 \\
Kertas & 17,46 \\
Plastik & 26,30 \\
Tekstil & 0,11 \\
Karet & 0,63 \\
Sampah Halaman & 12,55 \\
Kayu & 4,05 \\
\hline Total Organik & 89,42 \\
\hline Anorganik & \\
\hline Kaca & 1,65 \\
Logam non ferrous & 2,30 \\
Lain-lain & 6,63 \\
\hline Total Anorganik & 10,58 \\
\hline Total & 100 \\
\hline
\end{tabular}

Berdasarkan hasil perhitungan komposisi sampah didapatkan bahwa sampah dominan yang ada di Kawasan wisata Pantai Carocok Kota Painan adalah sampah sisa makanan dan plastik sebesar $28,32 \%$ dan 26,30\%. Sampah sisa makanan banyak yang berasal dari fasilitas rumah makan karena sebagian besar pengunjung di kawasan wisata pantai ini banyak yang memesan makanan maupun minuman di rumah makan ini. Sedangkan untuk sampah plastik ditemukan pada semua titik sampling yang telah ditentukan dengan jenis plastik yang berbeda-beda. Jenis sampah plastik yang banyak ditemukan saat penelitian ini berupa sampah botol minuman dan plastik pembungkus minuman dan mie instan yang banyak di beli oleh pengunjung di kawasan wisata.

\section{Potensi Daur Ulang}

Berdasarkan komponen sampah dari penelitian ini, persentase komposisi sampah berguna untuk penentuan potensi daur ulang dari masing-masing komponen dengan cara membandingkan berat masing-masing komponen yang dapat didaur ulang dengan berat total masingmasing komponen sampah. Komponen sampah yang dapat didaur ulang di Kawasan Wisata Pantai Carocok adalah sampah kertas, plastik, kaca, kayu, logam non ferrous dan sampah makanan. Potensi daur ulang dapat dilihat pada Tabel 5.

Tabel 5. Potensi Daur Ulang Sampah

\begin{tabular}{lcrr}
\hline Komponen & $\begin{array}{c}\text { Dapat di } \\
\text { daur ulang } \\
(\%)\end{array}$ & $\begin{array}{c}\text { Tidak dapat } \\
\text { didaur } \\
\text { ulang (\%) }\end{array}$ & Total (\%) \\
\hline Sampah & 47,454 & 52,546 & 100 \\
Makanan & & & \\
Kayu & 10,984 & 89,016 & 100 \\
Kertas & 24,018 & 75,982 & 100 \\
Plastik & 86,248 & 13,752 & 100 \\
Kaca & 54,887 & 45,113 & 100 \\
Logam & 93,550 & 6,450 & 100 \\
\hline
\end{tabular}

Berdasarkan Tabel 5 dapat dilihat bahwa potensi daur ulang sampah terbesar terdapat pada sampah jenis logam non ferrous sebesar 93,550\%, yang kedua terbesar adalah sampah plastik berupa botol minuman dari sampah pengunjung maupun pedagang sebesar $86,248 \%$. Selanjutnya adalah sampah kaca $54,887 \%$, dan untuk sampah lainnya memiliki potensi daur ulang yang lebih kecil dari $50 \%$.

\section{Kajian Awal Pengolahan Sampah}

Dari pengukuran yang dilakukan didapatkan bahwa timbulan sampah kawasan wisata Pantai Carocok adalah 6.149 L/hari, dengan komposisi terbesar adalah sampah makanan $28,32 \%$ yang diikuti oleh sampah plastik 26,30\% dan sampah kertas $17,46 \%$. Potensi daur ulang dari sampah yang dihasilkan terbesar adalah sampah logam non ferrous 93,550\% meskipun dari segi komposisi bagiannya cuma $2,30 \%$, diikuti oleh sampah plastik 86,248\% dan sampah kaca 
$54,887 \%$ meskipun bagiannya dalam sampah keseluruhan hanya $1,65 \%$.

Berdasarkan data timbulan, komposisi, dan potensi daur ulang ini maka dapat kita lihat potensi pengolahan sampah dari kawasan wisata ini adalah:

a. Sampah makanan, volume yang akan diolah adalah: $578,01 \mathrm{~kg} / \mathrm{h}$ ari $\mathrm{x} 28,32 \%$ x 47,454\% = 77,68 kg/hari,

b. Sampah plastik: $578,01 \mathrm{~kg} / \mathrm{hari} \mathrm{x}$ $26,30 \% \times 86,248 \%=131,11 \mathrm{~kg} / \mathrm{hari}$,

c. Sampah kertas: $578,01 \mathrm{~kg} / \mathrm{hari} \mathrm{x}$ $17,48 \%$ x $24,018 \%=24,27 \mathrm{~kg} / \mathrm{hari}$,

d. Sampah logam: $578,01 \mathrm{~kg} /$ hari x 2,30\% $\mathrm{x} 93,550 \%=12,44 \mathrm{~kg} / \mathrm{hari}$, dan

e. Sampah kaca: $578,01 \mathrm{~kg} /$ hari x $1,65 \%$ x $54,887 \%=5,23 \mathrm{~kg} / \mathrm{hari}$.

Sehingga total sampah yang dapat diolah sebesar 250,73 kg/hari (43,38\%).

Untuk Pengolahan sampah yang dapat di daur ulang dapat dilakukan dengan cara pengomposan dan daur ulang atau pemanfaatan kembali sampah dengan bentuk dan fungsi yang berbeda. Kegiatan pengolahan sampah dapat dilakukan pada bangunan tempat pengolahan sampah berbasis reduce-reuse-recycle (TPS 3R), yang dapat dibangun pada lokasi kawasan wisata terkait.

Kegiatan daur ulang awalnya dapat dilakukan dengan melakukan pemisahan dari sumber penghasil sampah berdasarkan jenis sampah. Selain itu, juga dapat dilakukan dengan cara menyediakan pewadahan untuk warna yang berbedabeda dari masing-masing jenis sampah. Wadah hijau untuk sampah makanan dan halaman, wadah biru untuk plastin, wadah kuning untuk plastik, putih untuk kaca, dan abu-abu untuk jenis sampah kaleng dan logam.

\section{KESIMPULAN}

Kesimpulan hasil penelitian sampah kawasan wisata Pantai Carocok Kota Painan adalah sebagai berikut:

1. Satuan timbulan sampah wisata Pantai Carocok Kota Painan dalam satuan berat adalah $0,012 \mathrm{~kg} / \mathrm{o} / \mathrm{h}$ dan dalam satuan volume adalah $0,307 \mathrm{l} / \mathrm{o} / \mathrm{h}$. Timbulan sampah total adalah $6.149 \mathrm{~L} /$ hari atau $578,01 \mathrm{Kg} / \mathrm{hari}$.

2. Komposisi sampah sampah kawasan wisata Pantai Carocok Kota Painan didominasi oleh sampah makanan 28,32\%, sampah plastik $26,30 \%$, dan sampah kertas $17,48 \%$.

3. Potensi daur ulang sampah kawasan wisata Pantai Carocok Kota Painan berturut-turut dari yang terbesar yaitu sampah logam non ferrous 93,550\%, sampah plastik $86,248 \%$, sampah kaca $54,887 \%$, dan sampah kertas $24,018 \%$.

4. Potensi sampah yang dapat diolah sebesar $43,38 \%$ dari total sampah yang dihasilkan tiap harinya. Pengolahan sampah yang dapat dilakukan berupa pengomposan sampah makanan, dan daur ulang sampah plastik, kertas, logam non ferrous, dan kaca. Pengolahan sampah dapat dilakukan pada TPS 3R yang dibangun di lokasi wisata Pantai Carocok Kota Painan.

Saran yang dapat diberikan untuk penelitian selanjutnya yang dapat menjadi masukan yaitu:

1. Penelitian dapat dilanjutkan dengan perencanaan pengelolaan sampah kawasan wisata Pantai Carocok Kota Painan;

2. Sebaiknya pengunjung diarahkan untuk membuang sampah pada tempat yang telah disediakan dan peraturan-peraturan yang ada mengenai sanksi membuang sampah sembarangan lebih di jalankan lagi;

3. Perencanaan pengelolaan sampah di kawasan wisata perlu adanya TPS 3R yang dapat melayani khusus untuk kawasan wisata.

\section{DAFTAR PUSTAKA}

G. P. Adfuza, "Perencanaan Sistem Pengelolaan Sampah Kawasan Wisata Pantai Padang, Sumatera Barat" Tugas Akhir Jurusan Teknik 
Lingkungan Universitas Andalas, Padang, 2019.

R. Aziz, Y. Dewilda, M. R. Putra," Kajian Awal Pengolahan Sampah Kawasan Wisata Minang Fantasi Waterpark (MiFan) Dan Wisata Pusat Dokumentasi Informasi Kebudayaan Minangkabau (PDIKM) Kota Padang Panjang," Prosiding 6 th ACE Conference. 29 Oktober 2019, Padang, Sumatra Barat. 2019

R. Aziz and Mira, "Study of recycling potential of solid waste of tourist area in Pariaman City," IOP Conf. Ser.: Mater. Sci. Eng. 602 012059, 2019.

R. Aziz, dan M. Putra, "Kajian Awal Sistem Pengelolaan Sampah Kawasan Wisata Danau Singkarak, Sumatera Barat," Prosiding Seminar Nasional Teknologi dan Pengelolaan Lingkungan Tropis, Pekanbaru, pp.113-119, 2019

R. Aziz, Y. Ruslinda, and N. Okavianus, "Development of Sustainable Solid waste management system of Air Manis Tourism Area for Supporting Sustainable Tourism in Padang City, West Sumatra, Indonesia," ASEAN/Asian Academic Society International Conference Proceeding Series, 611-617, 2019.

Badan Standardisasi Nasional, "SNI-193964-1994 tentang Metode Pengambilan dan Pengukuran Contoh Timbulan dan Komposisi Sampah Perkotaan," 1994.

Badan Standardisasi Nasional, "SNI-192454-2002 tentang Tata Cara Teknik Operasional Pengelolaan Sampah Perkotaan," 2002.

R.A. Bhat, R. Nazir, S. Ashraf, M. Ali, S.A. Bandh, and A.N. Kamili, Waste Manage Res. 32 165- 169, 2014.

E. Damanhuri, dan T. Padmi, "Pengelolaan Sampah Terpadu". Penerbit ITB, Bandung, 2016.

M.G. Hoang, T. Fujiwara, and S.T. Pham Phu, Journal of JSCE. 5 123-132, 2017.
K. M. Jefri, dan R. Aziz, "Studi Potensi Daur Ulang Sampah Kawasan Wisata Taman Marga Satwa dan Budaya Kinantan (TMSBK) dan Kawasan Wisata Taman Panorama dan Lobang Jepang (TPLJ) di Kota Bukittinggi," 5th ACE Conference. Padang, 2018.

J. Liu, J. Zhang, and Z. Fu, "Tourism ecoefficiency of Chinese coastal cities e Analysis based on the DEA-Tobit model," Ocean \& Coastal Management 148, 164-170. 2017.

M. Naltaru, R. Purmaini, dan R. Irsan,"Perencanaan Sistem Pengelolaan Sampah di Kawasan Wisata Bukit Kelam Kabupaten Sintang," Tugas Akhir Universitas Tanjungpura, Pontianak, 2014

R. Oktiasari, "Evaluasi Pengelolaan Sampah Wisata Gunungpring Kecamatan Muntilan Kabupaten Magelang Jawa Tengah Dengan Metode Zero Waste Index," Tugas Akhir. Jurusan Teknik Lingkungan, Universitas Islam Indonesia. 2018.

D. K. Purmada, Wilopo, dan L. Hakim, "Pengelolaan Desa Wisata Dalam Perspektif Community Based Tourism (Studi Kasus pada Desa Wisata Gubugklakah, Kecamatan Poncokusumo, Kabupaten Malang)," Jurnal Administrasi Bisnis (JAB), Vol. 32, No. 2, 2016.

M. Riva'i, "Perencanaan Sistem Pengelolaan Sampah Kawasan Wisata Lembah Harau Kabupaten Lima Puluh Kota," Tugas Akhir Jurusan Teknik Lingkungan Universitas Andalas, Padang, 2018.

E. Shamshiry, B. Nadi, M. BinMokhtar, I. Komoo, H.S. Hashim, and N. Yahaya, "Integrated Models for Solid Waste Management in Tourism Regions: Langkawi Island, Malaysia," Journal of Environmental and Public Health Volume 2011, Article ID 709549, 5 pages doi:10.1155/2011/709549, 2011.

R. S. Suzanna, "Peran Pariwisata Dalam Pembangunan," Badan Penerbit 
Universitas Diponegoro, Semarang, 2003.

G. Tchnobanoglous, and F. Kreith, "Handbook of Solid Waste Management" Second Edition, Mc Graw Hill Inc, New York, 2002.

G. Tchnobanoglous, S. Virgil, and H. Theisen, "Integrated Solid Waste Management," Mc Graw Hill Inc, New York, 1993.

Undang-Undang Republik Indonesia Nomor 18 Tahun 2008 tentang Pengelolaan Sampah, Jakarta, 2008.

V. R. Vitasurya, "SAWITRI (Sampah Wisata Pentingsari): Model Pengelolaan Sampah Aktivitas Wisata Desa Pentingsari, Yogyakarta," Tugas Akhir Universitas Atma Jaya Yogyakarta, Yogyakarta, 2014.

I.W. Wijaya dan Y. Trihadiningrum, "Strategi Penanganan Sampah di Objek Wisata Eks Pelabuhan Buleleng, Bali," Tugas Akhir Institut Teknologi Sepuluh Nopember, Surabaya, 2014.

Y. S. Yeni, "Perencanaan Sistem Pengelolaan Sampah Kawasan Nagari Tuo Pariangan," Tugas Akhir Jurusan Teknik Lingkungan, Universitas Andalas, 2019. 